\title{
EFEKTIVITAS PELAKSANAAN SUPERVISI \\ KEPALA BADAN TERHADAP KINERJA PEGAWAI \\ PADA BADAN PENELITIAN PENGEMBANGAN DAN PERENCANAAN (BALITBANGREN) KABUPATEN POLEWALI MANDAR
}

\author{
Mukhlis Hannan', Moch. Arfandi Adnan², Marsuki ${ }^{3}$ \\ ${ }^{1}$ Prodi Ilmu Pemerintahan, Fakultas Ilmu Sosial dan Ilmu Pemerintahan \\ Universitas Al Asyariah Mandar \\ Email:mukhlishannan@gamil.com \\ 2 Prodi Ilmu Pemerintahan, Fakultas Ilmu Sosial dan Ilmu Pemerintahan \\ Universitas Al Asyariah Mandar \\ Email: arfandiadnan1982@gmail.com
}

${ }^{3}$ Prodi Ilmu Pemerintahan, Fakultas Ilmu Sosial dan Ilmu Pemerintahan

Universitas Al Asyariah Mandar

Email: zukhi.marzu96@yahoo.com

\section{ABSTRACT}

This study aims to determine the effect of the implementation of the effectiveness of the Head of the Agency's supervision of the Employee Performance of the Research Development and Planning Agency of Polewali Mandar Regency. This research uses quantitative, and data collection techniques through a respondent approach by distributing questions about the variables of effectiveness, supervision, and performance. The results obtained from the development of supervision can be carried out effectively with the effectiveness of 50.6 while supervision is 48.8 and performance is 50.4. Developing performance by prioritizing maximum supervision can provide optimal results in improving the quality of employee performance. Overall, the implementation of supervision in the research agency for development and planning of Polewali Mandar Regency runs effectively.

\section{ABSTRAK}

Tujuan penelitian ini adalah untuk mengetahui pengaruh pelaksanaan efektivitas supervisi Kepala Badan terhadap Kinerja Pegawai Badan Penelitian Pengembangan dan Perencanaan Kabupaten Polewali Mandar. Penelitian menggunakan kuantitatif, dan teknik pengambilan data melalui pendekatan responden dengan cara menyalurkan beberapa pertanyaan mengenai variabel efektivitas, supervisi, dan kinerja. Hasil yang diperoleh pengembangan 
pengawasan dapat terlaksana secara efektif dengan efektivitas 50,6 sementara supervisi 48,8 dan kinerja 50,4. Mengembangkan kinerja dengan mengutamakan pengawasan secara maksimal dapat memberikan hasil secara optimal dalam peningkatan mutu kinerja Pegawai. Secara menyeluruh pelaksanaan supervisi di dalan badan penelitan pengembangan dan perencanaan Kabupaten Polewali Mandar berjalan secara efektif.

Kata Kunci: Efektivitas, Supervisi Dan Kinerja Pegawai Pegawai.

\section{PENDAHULUAN}

Indonesia sebagai bangsa yang sedang berkembang pada hakekatnya tidak terlepas dari berbagai bentuk fenomena-fenomena sosial yang terjadi dalam pembangunan. Titik sentral dari pembangunan adalah perberdayaan sumber daya manusia termasuk tenaga kerja, baik secara sasaran (obyek pembangunan) maupun sebagai pelaku (subyek pembangunan) maka dengan demikian pembangunan tenaga kerja merupakan salah satu aspek penting dari pembangunan nasional. Pembangunan ketenaga kerjaan sebagai bagian dari upaya pengembangan sumber daya manusia serta kepercayaan pada diri sendiri. Pembangunan ketenaga kerjaan merupakan upaya yang sifatnya menyeluruh di semua sektor daerah dan ditunjukan pada perluasan lapangan kerja, pemerataan kesempatan kerja, peningkatan mutu dan kemampuan, serta perlindungan tenaga kerja.

Badan Penelitian Pengembangan dan Perencanaan (Balitbangren) merupakan sebuah lembaga teknis daerah yang ada di Kabupaten Polewali Mandar dibidang Penelitian Pengembangan dan Perencanaan Daerah yang dipimpin oleh Kepala Badan yang dapat mengontrol bawahan secara maksimal sehingga Kepala Badan memiliki peran penting dalam peningkatan kinerja yang ada di Badan Penelitian Pengembangan dan Perencanaan Kabupaten Polewali Mandar.

Pihak Supervisi bertugas untuk mengusahakan agar suatu kinerja dalam instansi dapat terlaksana dengan semestinya serta waktu yang cukup efisien. Instansi secara memuaskan sebagian besar tergantung dari kualitas supervisi. Sehingga banyak yang menghambat dalam suatu pekerjaan mulai dari problem-problem yang ada di sebuah lembaga serta masalah-masalah supervisi.

Supervisi adalah sebuah peran dalam sebuah organiasi pemerintahan sekaligus memiliki figural utama dalam kepemimpinan. dimana sebuah keputusan harus melalui dari bawah. Suatu organisasi yang ada di Badan Penelitian Pengembangan dan Perencanaan dapat efektif atau tidak efektif yang dilakukan di sebuah instansi. Tergantung dari Supervisi yang dilakukan sebuah pimpinan. 
Efektivitas Pelaksanaan Supervisi Kepala Badan terhadap Kinerja Pegawai pada Balitbangren Kab. Polewali Mandar

Supervisi mempunyai suatu strategis dalam suatu kedudukannya dengan cara mempengaruhi dan membantu menyelesaikan kinerja yang ada, sehingga atasan memberikan arahan kepada bawahan melalui pengawasan, bimbingan serta pembinaan. Agar dalam instansi berjalan dengan maksimal melalui supervisi yang dilakukan dalam organisasi.

Seorang Supervisi dalam suatu pekerjaan memiliki titik kontak antara sebuah instansi agar kinerja dapat terlasurkan melalui anggota-anggota menajemen dan para pekerja operatif agar dapat berkonsentrasi. Instansi harus memiliki sebuah ukuran keberhasilan maupun kegagalan menjalankan tugas pokok dan fungsi karena belum adanya suatu sistem pengukuran kinerja yang dapat berhasil secara obyektif dan terarah dari sebuah instansi pemerintahan. Melalui pengukuran kinerja pelaksanaan program-program yang ada dalam sebuah organisasi.

Efektivitas pemimpin dipengaruhi karakteristik bawahannya dan terkait dengan proses komunikasi yang terjadi antara pemimpin dan bawahan. Pemimpin dapat dikatakan berhasil apabila dapat memberikan pembinaan dan motivasi terhadap suatu bawahan yang lebih baik sementara pemimpin tidak berhasil apa bila tidak dapat memotivasi, menggerakan serta mengawasi pegawai pada suatu pekerjaan dan lingkungan tertentu.

\section{METODE PENELITIAN}

Penelitian menggunakan metode kuantitatif agar mendapat hasil yang lebih baik dengan menggunakan analisis data melalui hubungan antara variabel. Variabel yang dikaji melalui penelitian ini yaitu efektivitas sebagai variabel bebas (X1), supervisi (X2) dan kinerja sebagai variabel terikat (Y).

Skor pilihan jawaban skala likert tergantung pada sifat pernyataan dengan penentuan skor yang digunakan adalah: skor 5 untuk jawaban Sangat Setuju (SS), skor 4 untuk jawaban Setuju (S), skor 3 Untuk Jawaban Netral (N), skor 2 untuk jawaban Tidak Setuju (ST), skor 1 untuk jawaban Sangat Tidak Setuju (STS).

Untuk skor rata-rata maka jumlah jawaban kuesioner dibagi jumlah penyataan dikalikan jumlah responden. Untuk lebih jelas berikut rumusnya:

$$
\text { Skor Rata-rata }=\frac{\sum \text { Jawaban Kuesioner }}{\sum \text { Pernyataan } \times \text { Responden }}
$$

Setelah diketahui skor rata-rata maka hasil tersebut dimasukan ke dalam garis kontinum dengan kecenderungan jawaban responden akan didasarkan pada nilai rata-rata skor yang selanjutnya akan dikatagorikan pada rentang skor sebagai berikut : 


$$
r=\frac{S T-S R}{K}
$$

Dimana :

$$
\begin{array}{ll}
\text { R } & =\text { Rentang/skala } \\
\text { ST } & =\text { Skor jawaban tertinggi } \\
\text { SR } & =\text { skor jawaban terendah } \\
\text { K } & =\text { Kategori }
\end{array}
$$

\section{HASIL PENELITIAN}

Data hasil penelitian terdiri dari dua variabel bebas yaitu Efektifitas (X1) dan Supervisi (X2) dan satu variabel terikat yaitu Kinerja (Y). untuk mendeskripsikan dan menguji pengaruh variabel bebas dan variabel terikat dalam penelitian ini, maka pada bagian ini akan disajikan deskripsi data dari masing-masing variabel berdasarkan data yang diperoleh dilapangan.

Berdasarkan hasil dari judul "Efektivitas Pelaksanaan Supervisi Kepala Badan Terhadap Kinerja pegawai Pada Badan Penelitian Pengembangan Dan Perencanaan (Balitbangren) Kabupaten Polewali Mandar dikatakan efektif apabila dapat dilihat dari 10 indikator. variabel Efetivitas (X1) dari tabel dibawah ada 50 responden yaitu prestasi kerja dengan persentasi setuju sebanyak 48. Sementara kepuasan kerja mempunyai persentasi setuju sebanyak 62. Menyesuaikan diri dengan persentasi setuju sebanyak 46 sehingga. perencanaan yang matang persentasi setuju sebanyak 54. Tersedianya sarana dan prasarana dengan persentasi setuju sebanyak 62. Penilaian dari pihak luar dengan persentasi setuju sebanyak 62. Kecepatan dalam menyelesaikan pekerjaan persentasi setuju sebanyak 54. Kemampuan menyesuaikan ide dengan persentasi setuju sebanyak 46. Semangat kerja dengan persentasi setuju sebanyak 36. Adapun komunikasi terbuka dengan persentasi setuju sebanyak 54. Dari penjelasan diatas bahwa nilai rekapitulasi nilai rata-rata variabel efektivitas 50,6 dalam suatu efektifitas mempunyai hasil yang efektif.

Variabel Supervisi (X2) hasil yang diperoleh dibagikan melalui kuesioner oleh responden dengan berjumlah 50 orang serta 10 indikator yaitu Pengamatan dengan persentasi setuju sebanyak 38. Diskusi antara pimpinan dan bawahan persentasi setuju sebanyak 52. Evaluasi dengan persentasi setuju sebanyak 52. Pelaksanaan dengan persentasi setuju sebanyak 48. Pembagian tugas dengan persentasi setuju sebanyak 50. Penilaian dengan persentasi setuju sebanyak 54. Pembinaan dengan persentasi setuju sebanyak 32. Tata tertib dengan persentasi setuju sebanyak 58. Pelaksanaan tugas dengan persentasi setuju sebanyak 46 dan pengelolaan anggaran dengan persentasi setuju 54. dari 
penjelasan diatas melalui supervisi memiliki rekapitulasi nilai rata-rata 48,8 sehingga belum dapat dikatkan efektif.

Variabel Kinerja (Y) Hasil yang diperoleh dilapangan melalui kuesioner oleh responden dengan berjumlah 50 orang serta 10 indikator yaitu indikator Kuantitas dengan persentasi setuju sebanyak 42. Indikator Kualitas dengan persentasi setuju sebanyak 50. Indikator Ketetapan Waktu dengan persentasi setuju sebanyak 56. Indikator Efektifitas dengan persentasi setuju sebanyak 52 . Indikator Kemandirian dengan persentasi setuju sebanyak 62. Indikator Kehadiran dengan persentasi setuju sebanyak 44. Indikator Tanggung Jawab dengan persentasi setuju sebanyak 54. Indikator Kerja Sama Tim dengan persentasi setuju 46. Indikator Kemampuan Mengatur Pekerjaan dengan persentasi setuju sebanyak 52 dan Indikator Disiplin Ilmu dengan persentasi setuju sebanyak 46. sehingga dari penjelasan di atas melalui kinerja memiliki rekapitulasi nilai rata-rata 50,4 sehingga sudah dikatakan efektif.

\section{Tabel 1}

Rekapitulasi Nilai Rata-Rata Dari Variabel Penelitian

\begin{tabular}{|l|l|c|}
\hline NO. & \multicolumn{1}{|c|}{ URAIAN } & NILAI \\
\hline 1. & EFEKTIVITAS & 48 \\
& $-\quad$ Pretasi kerja & 62 \\
& - Kepuasan kerja & 46 \\
& - Menyesuaikan diri & 54 \\
& - Perencanaan yang matang & 62 \\
& - Sarana dan prasarana & 62 \\
& - Penilaian dari pihak luar & 54 \\
& - Kecepatan dalam menyesuaikan & 46 \\
& - Menuesuaikan ide & 36 \\
& - Semangat kerja & 36 \\
\hline & - Komunikasi terbuka & $\mathbf{5 0 , 6}$ \\
\hline 2. & SUPERILATA-RATA & 42 \\
& - Pengamatan & 52 \\
& - Diskusi antara pimpinan dan bawahan & 52 \\
& - Evaluasi & 48 \\
& - Pelaksanaan & 50 \\
& - Memberikan pembagian tugas & 54 \\
& - Penilaian & 32 \\
& - Pembinaan & 58 \\
& - Tata tertib & 46 \\
& - Pelaksanaan tugas & 54 \\
\hline & - Pengelolaan anggran & $\mathbf{4 8 , 8}$ \\
\hline
\end{tabular}




\begin{tabular}{|l|l|c|}
\hline 3. & KINERJA & \\
& - Kuatitas & 42 \\
& - Kualitas & 50 \\
& - Ketetapan waktu & 56 \\
& - Efeltivitas & 52 \\
& - Kemandirian & 62 \\
& - Kehadiran & 44 \\
& - Bertanggung jawab & 54 \\
& - Kerja sama tim & 46 \\
& - Kemampuan mengatur pekerjaan & 52 \\
& - Disiplin kerja & 46 \\
\hline & \multicolumn{2}{|c|}{ NILAI RATA-RATA } \\
\hline
\end{tabular}

Sumber Data : Diperoleh Dari Hasil Penelitian Balitbangren Tahun 2020

Penjelasan dari tabel diatas melalui rekapitulasi nilai rata-rata dari variabel penelitian yaitu efektivitas mempunyai nilai yang tinggi sebanyak 50,6 sementara Kinerja mempunyai nilai rata-rata 50,4 dan yang paling rendah dari ke tiga variabel yaitu 48,8 .

Hasil penelitian yang ada di lapangan melalui analisis data kuesioner yang dibagikan oleh responden yaitu 50 orang menunjukan bahwa variabel efektivitas (X1) mempunyai nilai rata-rata sebanyak 50,6 sehingga dalam suatu instansi dimana efektivitas mempunyai nilai yang tinggi dari pada variabel lainnya.

Efektivitas dapat dipengaruhi oleh suatu prestasi kerja dari suatu organisasi, kepuasan kerja untuk memperoleh hasil maksimal, menyusaikan diri, mempunyai perencanaan yang matang, sarana dan prasarana, penilaian dari pihak luar mengenai hasil kinerja, kecepatan dalam menyelesaikan pekerjaan, kemampuan menyusaikan ide, semangat kerja yang dilakukan suatu organisasi, serta komunikasi terbuka antara suatu kelompok.

Hasil yang menunjukan bahwa variabel Supervisi (X2) yang dilakukan Kepala Badan terhadap Pegawai Badan Penelitian Pengembangan Dan Perencanaan. Sehingga nilai rata-rata dari Supervisi sebanyak 48,8 melalui data yang ada dilapangan, karena disetiap indikator berjumlah 10 dalam setiap variabel.

Supervisi yang dilakukan oleh pimpinan dapat dipengaruhi oleh pengamatan terhadap Pegawai, diskusi antara pimpinan dan bawahan, evaluasi Kepala Badan Terhadap Bawahan, pelaksanaan yang diberikan oleh bawahan, memberikan pembagian tugas kepada bawahan yang lebih mengetahui di bidang masing-masing, penilaian Kepala Badan terhadap bawahan, pembinaan kepada bawahan agar dapat memberikan motivasi kepada bawahan, tata tertib 
Efektivitas Pelaksanaan Supervisi Kepala Badan terhadap Kinerja Pegawai pada Balitbangren Kab. Polewali Mandar

yang dibuat dalam suatu instansi berjalan dengan baik, pelaksanaan tugas kepada bawahan, serta Kepala Badan dan bawahan dapat mengelolaan anggaran yang optimal.

Variabel kinerja (Y) yang ada di Badan Penelitian Pengembangan Dan Perencanaan yang mempunyai 10 indikator, suatu kinerja yang dilakukan oleh seorang individu maupun kelompok harus mempunyai tujuan yang ingin dicapai, sehingga dalam suatu penelitian Kinerja mempunyai nilai rata-rata sebanyak 50,4 .

Kinerja pegawai dapat dipengaruhi oleh kuantitas pegawai, kualitas, ketetapan waktu oleh pimpinan dan bawahan, efektivitas, kemandirian, kehadiran semua pegawai, bertanggung jawab dalam suatu kinerja, kerja sama tim dalam suatu organisasi, kemampuan mengatur pekerjaan, serta disiplin kerja dalam suatu kinerja pegawai balitbangren.

Jumalia Mannayong (2018)dengan penelitian "efektivitas kinerja pegawai pada Dinas Pendidikan Pemuda Dan Olahraga Kabupaten Takalar" Sekolah Tinggi Ilmu Administrasi Negara Makassar.

Berdasarkan perolehan observasi dari efektivitas kinerja pegawai pada Dinas Pendidikan Pemuda Dan Olahraga Kabupaten Takalar telah efektif karena pencapaian dari semua program yang ada dalam rencana kerja (Renja) telah berhasil 90\% sehingga efektivitas kinerja pegawai Dinas Pemuda Dan Olahraga Kabupaten Takalar sudah biasa dijadikan contoh oleh Kantor Pemerintah lainnya. Meskipun masih ada yang harus diperbaiki dan menjadi kendala bagi efektivitas kinerja pegawai seperti terbatasnya kemampuan sumber daya manusia seperti kemampuan dalam menguasai Bahasa asing yang menjadi perihal penting pada era global saat ini.

Hasil Penelitian yang dilakukan tidak sesuai dengan peneliti terdahulu yang mempunyai nilai efektitivitas sebanyak 50,6. Supervisi 48,8 dan kinerja sebanyak 50,4 sehingga dari hasil penelitian ini masi efektif secara maksimal.

Teori efektifitas menurut Menurut subagyo (2000) efektivitas adalah "kesesuaian antara Output dengan tujuan yang diharapkan". Dari teori diatas belum sesuai dengan hasil penelitian yang dilakukan karena belum terlalu efektif dari hasil yang yang dilakukan peneliti. Sehingga dari nilai rata-rata rekapitulasi sebanyak 50,6.

Menurut Raphael R. Kavanaugh dan Jack D. Ninemeier (2001) Supervisi adalah seseorang yang bertanggung jawab mengelola karyawan level bawah atau karyawan lainnya yang tidak mempunyai bawahan. Sehingga dari supervisi yang ada di Badan Penelitian Pengembangan Dan Perencanaan tidak sesuai dengan teori yang ada diatas karena belum terlalu optimal yang dilakukan Pimpinan karena masi ada beberapa bawahan yang tidak mengikuti 
aturan dalam sebuah lembaga contoh masi adanya pegawai yang jarang masuk kerja. Disinilah kurangnya supervisi yang dilakukan Pimpinan. Sehingga nilai rata-rata rekapitulasi dari supervisi sebanyak 48,8 .

Menurut anwar prabu (2204:67) pengertian kinerja adalah "hasil kinerja secara kualitas dan kuantitas yang dicapai oleh seorang karyawan dalam melaksanakan tugasnya sesuai dengan tanggung jawab yang diberikan kepadanya". Melalui kinerja yang dilakukan pegawai balitbangren belum maksimal karena masi ada beberapa pegawai yang belum melaksanakan tanggung jawab yang diberikan dan nilai rata-rata rekapitulasi kinerja sebanyak 50,4 sehingga dari teori diatas belum sesuai dari hasil penelitian.

Beberapa faktor pendukung melaksanakan supervisi terhadap bawahan seperti membangun hubungan harmonis terhadap pegawai, membangun komunikasi dan memberikan bimbingan khusus terhadap pegawai. Kepala Badan maupun bidang sangat berpengaruh untuk meningkatkan kualitas kinerja melalui pendekatan supervisi secara efektif bertujuan merubah metode bersifat universal dan adapun pengaruh dari sebuah pelaksanaan supervisi yang ada di Badan Penelitian Pengembangan dan Perencanaan belum terlalu maksimal karena mempunyai nilai dalam supervisi

Disimpulkan dari sebuah indikator melalui responden yang berjumlah 50 orang yaitu PNS dan Non PNS bahwa suatu instansi yang ada di Balitbangren sudah bisa kita ambil contoh walaupun masi kurangnya pengawasan yang dilakukan pimpinan. menunjukan bahwa Badan Penelitian Pengembangan Dan Perencanaan di Kabupaten Polewali Mandar belum terlalu maksimal dalam mengawasi bawahan.

Diterapkannya supervisi dapat meningkatkan hasil kinerja yang lebih tinggi. Yaitu salah satunya adalah meningkatkan Supervisi. Agar bawahan dapat termotivasi untuk terus bekerja dan meningkatkan hasil yang lebih baik dalam suatu instansi

\section{KESIMPULAN}

Berdasarkan hasil penelitian dapat disimpulkan bahwa tanggung jawab yang diemban Kepala Badan Penelitian Pengembangan dan Perencanaan (Balitbangren) Kabupaten Polewali Mandar merupakan kinerja pegawai secara professional pada Badan tersebut dengan mengefektifkan pelaksanaan Supervisi sehingga dapat disimpulkan bahwa pelaksanaan supervisi mempunyai nilai rata-rata 48,8 adapun efektivitas yaitu 50,6 dan kinerja mempunyai nilai rata-rata sebanyak 50,4 disini menunjukan bahwa supervisi mempunyai nilai yang paling rendah. 
Efektivitas Pelaksanaan Supervisi Kepala Badan terhadap Kinerja Pegawai pada Balitbangren Kab. Polewali Mandar

Beberapa faktor pendukung melaksanakan supervisi terhadap bawahan seperti membangun hubungan harmonis terhadap pegawai, membangun komunikasi dan memberikan bimbingan khusus terhadap pegawai. Kepala Badan maupun bidang sangat berpengaruh untuk meningkatkan kualitas kinerja melalui pendekatan supervisi secara efektif bertujuan merubah metode bersifat universal dan adapun Penghambat dalam Beberapa faktor penghambat terlaksananya supervisi untuk meningkatkan kinerja pegawai yaitu kurangnya atasan memberikan pengawasan terhadap bawahan secara langsung mengakibatkan keterbatasan membangun komunikasi untuk meningkatkan kinerja di dalam instansi bersifat stagnan. Asal muasal menjadi tujuan mengembangkan kinerja dalam Instansi melalui pembangunan perencanaan pegawai yang bermutu.

\section{SARAN}

Kepada pihak aparat keamanan baik itu TNI, Polri, Satpol PP agar kiranya lebih tegas dalam mengamankan para pelaku pemungutan liar retribusi parkir terutama kepada para juru parkir liar, sehingga kedepannya prakterpraktek pemungutan liar tidak terjadi lagi. Kepada para kolektor dan juru parkir agar kiranya dapat melaksanakan tugasnya dengan lebih baik lagi dan penuh rasa tanggungjawab serta sesuai dengan aturan-aturan yang ada.

Kepada Pemerintah Kabupaten Polewali Mandar kiranya melakukan sosialisasi terkait Peraturan Daerah nomor 2 tahun 2018 terutama tarif dan wajib bayar bagi para pengguna parkir di jalan terutama di Pasar Sentral Pekkabata. Dan juga untuk memeperbaiki administrasi data-data seputar Pasar Sentral Pekkataba, sebab dalam penelitian penulis sulit menemukan data-data jadi perlu adanya proses revitalisasi administrasi Pasar Sentral Pekkabata agar kelak peneliti-peneliti yang lain tidak mengalami kesulitan yang sama dengan penulis.

\section{DAFTAR PUSTAKA}

Ahmad, Faizurah. 2014. Efektivitas Kinerja Pegawai Dinas Sosial Prov. Sul-Sel. Universitas Hasanuddin

Arikunto, Suharsimi. 1990. Organisasi dan Administrasi. Jakarta: Rajawali pers

Makawimbang, Jerry H. 2011. Supervisi dan Peningkatan Mutu Pendidikan. Bandung: Alfabeta.

Mannayong, Jumalia. 2018 "Efektivitas kinerja pegawai pada dinas Pendidikan pemuda dan olahraga Kabupaten Takalar" Kampus Sekolah Tinggi Ilmu Administrasi Negara, Makassar.

Nawawi, Hadari dan Martini Hadari, Instrumen Penelitian Bidang Sosial 
Nuraida, Ida. 2014. Manajemen Administrasi perkantoran. Yogyakarta: kanisuis.

Putra, Tri Arga "Efektivitas Kinerja Pegawai Kantor Camat Sentajo Raya Kabupaten Kuantan Singingi" Universitas Riau.

Shadily, Hasan. 1983. Sosiologi untuk Masyarakat Indonesia. Cet. IX; Jakarta: Bina Aksara.

Warsidi, Adi. 1986. Administrasi Perkantoran, Universitas Terbuka, Jakarta.

Winardi, 1990. Manajemen Perkantoran dan Pengawasan, Bandung. 